\title{
A necrotising ulcer after rescuing a kitten
}

\author{
Marieke Zijlstra, ${ }^{1}$ Ab Osterhaus, ${ }^{2}$ Jojanneke Heidema ${ }^{1}$
}

${ }^{1}$ Department of Paediatrics, St Antonius Hospital, Nieuwegein, Utrecht, The Netherlands ${ }^{2}$ Department of Virology, Erasmus University, Rotterdam, The Netherlands

\section{Correspondence to} Dr Jojanneke Heidema, j.heidema@antoniusziekenhuis. nl

\section{DESCRIPTION}

A 17-year-old previously healthy girl from the Netherlands presented with a history of 8 days of fever, malaise and a necrotic wound on her left wrist.

Two weeks before presentation she had cut herself in her left wrist. Several hours later she rescued a kitten from a ditch. The kitten was sick and died the following day. Over 2 weeks, the cut became a large red wound, blistered before turning black. In this period she was treated with amoxicilline-clavulinate and cefuroximaxetil, cultures grew Staphylococcus aureus. However, these drugs had no effect on the injury.

Physical examination at the hospital showed a $2-3 \mathrm{~cm}$ wound on her left wrist. A necrotic ulcer was surrounded by an erythematous infiltrated area (figure 1). There were multiple painful red nodules on her left arm, reaching from the wound to her axilla (figure 2). She had a rash all over her body and a temperature of $38.2^{\circ} \mathrm{C}$.

Initial laboratory results showed: C-reactive Protein (CRP) $70 \mathrm{mg} / \mathrm{L}$, leucocyte count $8.4 \times 109$ cells $/ \mathrm{L}$. The differential diagnosis of a necrotic ulcer includes bacterial infection (Pseudomonas aeruginosa), abscess, leptospirosis, antrax and cowpox virus. From the clinical picture cowpox virus infection was suspected, PCR and serology were therefore carried out. PCR analysis and IgM serology were both positive, confirming our diagnosis. After a week her clinical condition had improved. The wound healed within 2 months, leaving a scar.

Cowpox virus infection in humans is uncommon and mainly seen in Europe. Humans in contact with infected cats, cows or small rodents can

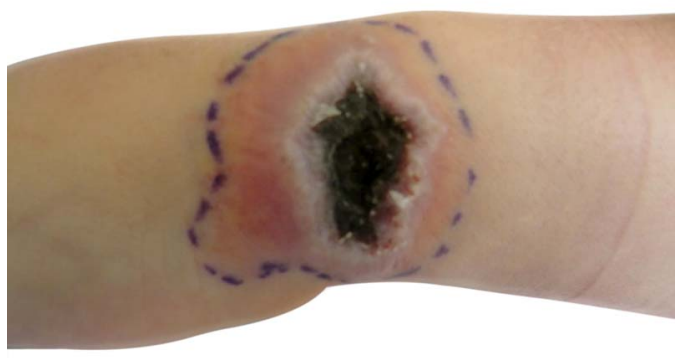

Figure 1 Necrotic ulcer on left wrist.

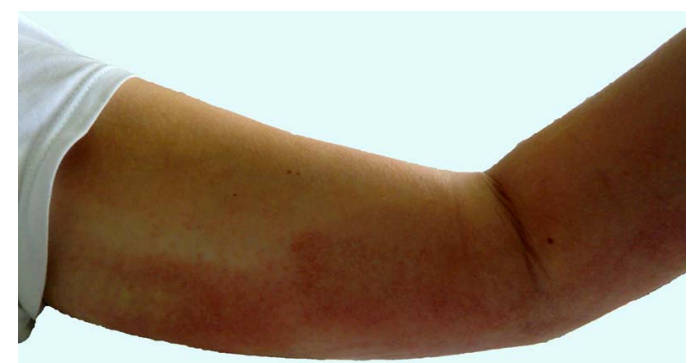

Figure 2 Lymphadenitis.

become infected. Necrotic ulcer, erythema and lymphadenitis are typical presentations, flu-like symptoms might be present in the acute phase. ${ }^{1}$ Cowpox virus belongs to the Poxviridae family and Chordopoxvirinae subfamily. Infection in immunocompetent individuals is a self-limiting disease. ${ }^{2}$

\section{Learning points}

- Cowpox virus should be considered on presentation of a necrotic ulcer and a history of contact with pets or small rodents.

- Cowpox can be diagnosed both by PCR and serology.

- Cowpox virus infection is a self-limiting disease that may take up to 6 weeks to heal. The wound may leave a scar.

Contributors All the authors were involved in clinical management of the case as well as acquisition and interpretation of the diagnostic testing. MZ wrote the article, which was critically and substantially revised by $\mathrm{JH}$ and $\mathrm{AO}$. All authors have approved the final version of the manuscript.

Competing interests None.

Patient consent Obtained.

Provenance and peer review Not commissioned; externally peer reviewed.

\section{REFERENCES}

1 Vogel S, Sárdy M, Glos K, et al. The Munich outbreak of cutaneous cowpox infection: transmission by infected pet rats. Acta Derm Venereol 2012;92:126-31.

2 Wolfs TF, Wagenaar JA, Niesters HG, et al. Rat-to-human transmission of Cowpox infection. Emerg Infect Dis 2002;8:1495-6.
To cite: Zijlstra $\mathrm{M}_{\text {, }}$

Osterhaus A, Heidema J. BMJ Case Rep Published online: [please include Day Month Year] doi:10.1136/ bcr-2013-010398 
Copyright 2013 BMJ Publishing Group. All rights reserved. For permission to reuse any of this content visit http://group.bmj.com/group/rights-licensing/permissions.

BMJ Case Report Fellows may re-use this article for personal use and teaching without any further permission.

Become a Fellow of BMJ Case Reports today and you can:

- Submit as many cases as you like

- Enjoy fast sympathetic peer review and rapid publication of accepted articles

- Access all the published articles

- Re-use any of the published material for personal use and teaching without further permission

For information on Institutional Fellowships contact consortiasales@bmjgroup.com

Visit casereports.bmj.com for more articles like this and to become a Fellow 